\title{
Effect of Different Levels of NPK and Zinc on Soil Health Growth and Yield of Chickpea (Cicer arietinum L.) var. PUSA 362
}

\author{
Ankur Sahu*, Narendra Swaroop, Arun Alfred David and Tarence Thomas \\ Department of Soil Science and Agricultural Chemistry, Naini Agricultural institute, \\ Sam Higginbottom University of Agriculture, Technology and Sciences, \\ Prayagraj 211007 U.P. India \\ *Corresponding author
}

\begin{tabular}{l} 
Ke y w or d s \\
$\begin{array}{l}\text { Chickpea, NPK, } \\
\text { Zinc, EC, pH, Yield }\end{array}$ \\
\hline Article Info \\
$\begin{array}{l}\text { Accepted: } \\
\text { 07 September } 2020 \\
\text { Available Online: } \\
\text { 10 October } 2020\end{array}$ \\
\hline
\end{tabular}

The study entitled The Effect of different level of NPK and Zinc on soil health, growth and yield of Chickpea (Cicer arietinum L.). Cv-Pusa-362 was carried out at the research farm of Soil science and agriculture chemistry, Sam Higginbottom University of Agriculture, Technology and Science, Prayagraj during the season of Rabi 2019-20. The soil of the experimental area was sandy loam in texture. The experiment was laid out in randomized block design with three levels of N P \& K $(0 \%, 50 \%$ and $100 \%)$ and three levels of Zinc $(0 \%, 50 \%$ and $100 \%)$. The experimental results revealed that significantly maximum growth parameters like plant height $(42.9 \mathrm{~cm})$, number of branches (19.6) and yield attributes like number of pods (63.1), number of seeds pods ${ }^{-1}(1.6)$, test weight $(28.38 \mathrm{~g})$, total grain yield $\left(25.13 \mathrm{q} \mathrm{ha}^{-1}\right)$ were noticed under $\mathrm{T}_{9}(@ 100 \% \mathrm{NPK}+100 \% \mathrm{Zn})$ as compared to rest of the treatments and lowest under $\mathrm{T}_{1}$ (Control). And the result shows that $\mathrm{pH}, \mathrm{EC}\left(\mathrm{dSm}^{-1}\right)$, Bulk density $\left(\mathrm{Mg} \mathrm{m}^{-3}\right)$, Particle density $\left(\mathrm{Mg} \mathrm{m}^{-3}\right)$, Pore space (\%), Organic carbon $(\%)$, available Nitrogen $\left(306.24 \mathrm{~kg} \mathrm{ha}^{-1}\right)$, phosphorus $\left(28.96 \mathrm{~kg} \mathrm{ha}^{-1}\right)$, potassium $\left(210.23 \mathrm{~kg} \mathrm{ha}^{-1}\right)$ and Zinc $\left(0.89 \mathrm{~kg} \mathrm{ha}^{-1}\right)$ on the soil showed significant effect with $\mathrm{T}_{9}$ (@100 $\% \mathrm{NPK}+100 \% \mathrm{Zn}$ ). Maximum gross return, net return (Rs.124849) and B:C ratio (1:4.24) were also recorded with the treatment $\mathrm{T}_{9}$ (@100\% NPK + $100 \% \mathrm{Zn}$ ).

\section{Introduction}

Pulses are a major source of proteins among the vegetarians in India, and complement the staple cereals in the diets with proteins, essential amino acids, vitamins and minerals (Pingoliya et al., 2013). They contain 22 to $24 \%$ protein, which are almost twice the protein in wheat and thrice that of rice (Shukla et al., 2013). It is an easily available source of protein in the rural heart of India that is village. According to the International Crops Research Institute for the Semi-Arid Tropics (ICRISAT) chickpea seeds contain on average- $21.1 \%$ protein, $64 \%$ total carbohydrates $(47 \%$ starch, $6 \%$ soluble sugar), $5 \%$ fat, $6 \%$ crude fiber and $3 \%$ ash. High mineral content has been reported for phosphorus (340 mg per $100 \mathrm{~g}$ ), calcium (190 $\mathrm{mg}$ per $100 \mathrm{~g}$ ) and magnesium (140 mg per $100 \mathrm{~g}$ ), iron (7 mg per $100 \mathrm{~g}$ ) and zinc (3 mg per $100 \mathrm{~g})$. Balanced fertilizer application in a 
cropping system is very necessary for a sustainable production system as well as appropriate soil nutrient flexibility. Increasing the level of NPK up to $100 \%$ RDF significantly improved growth parameters, yield attributes, grain and straw yield (Verma et al., 2018). The effect of $\mathrm{N}$ fertilizer application on soil organic matter status and soil physical properties is important to agricultural sustainability and to increase crop yield (Zhong et al., 2014). Under dry land conditions nitrogen increases the growth and development, dry matter production and yield of crops (Dinesh, 2014). Beside this phosphorus is also an important fertilizer in chickpea production, it is a very important chemical fertilizer (Dotaniya et al., 2013) that can raise the water holding capacity of soil. Potassium is very effective in the nodulation of pulse crops thus increases the seed yield through better fixation of nitrogen (Rajput 2018). It also increases the $\mathrm{pH}$ of soil and plays a major role in the regulation of water. Late application of $\mathrm{Zn}$ especially at the seed filling period increased the ability of chickpea plants to use nitrogen effectively (Mohamed et al., 2016).

\section{Materials and Methods}

\section{Experimental site}

The study was carried out at the research farm of Soil science and agriculture chemistry Prayagraj, during the season of Rabi 20192020. The farm is located at 2502430 " North latitude 810 51'10" East longitude and $98 \mathrm{~m}$ above mean sea level.

The complete detail of the treatment combination is given in table 1 .

\section{Treatment combinations}

Laboratory analysis- the bulk and particle density of soil was determined by graduate measuring cylinder and $\mathrm{pH}$ and $\mathrm{EC}$ by Glass electrode $\mathrm{pH}$ meter and Digital Conductivity meter. Organic carbon was determined by rapid titration method given by Walkley and Black (1934). Available N was determined by alkaline permanganate method (Subbiah and Asija 1956), available $\mathrm{P}$ by Olsen et al., (1954), available K by Flame photometric method (Toth and Prince, 1949) and available Zn by Shaw and Dean1952 (Table 2 and 3).

\section{Economic parameters in treatment}

Treatment-wise the input and output cost was calculated with the help of different economic parameters like, Net profit and B:C ratio etc.

\section{Results and Discussion}

In table 4 and 5 we can see the significant and non significant effect of different level of NPK and Zinc on yield, physical and chemical properties of soil.

Plant height $(\mathrm{cm})$ - the effect of treatment on plant height ware significant in 30, 60, 90 and 120 days. At 30, 60, 90 and 120 days maximum plant height $(11.4 \mathrm{~cm}),(20.8 \mathrm{~cm})$, $(32.8 \mathrm{~cm})$ and $(42.9 \mathrm{~cm})$ ware recorded at $\mathrm{T}_{9}$ (NPK 100\%, Zn 100\% 20:40:20Kg NPK+20 $\mathrm{Kg} \mathrm{Zn} \mathrm{ha}{ }^{-1}$ ) respectively. The minimum plant height $(9.7 \mathrm{~cm}),(18.7 \mathrm{~cm}),(30 \mathrm{~cm})$ and $(39.7$ $\mathrm{cm})$ ware recorded in 30, 60, 90 and 120 days respectively with $\mathrm{T}_{1}$ (Control). Similar result was obtained by Darvhankar et al., (2019). The effect of NPK and Zinc on number of branches was also significant. At 30, 60, 90 and 120 days maximum number of branches (10.4), (14.1), (17.5) and (19.6) was recorded at $\mathrm{T}_{9}$ (NPK 100\%, Zn 100\% 20:40:20Kg $\mathrm{NPK}+20 \mathrm{Kg} \mathrm{Zn} \mathrm{ha}^{-1}$ ) respectively. The minimum number of branches (8.3), (12.3), (15) and (16.8) was recorded respectively with $\mathrm{T}_{1}$ (Control). Similar result was obtained by Darvhankar et al., (2019). There is significant effect of treatment on the number 
of pods plant ${ }^{-1}$, number of seeds pod ${ }^{-1}$, seed weight and total grain yield Verma et al., (2018). The maximum number of pods plant ${ }^{-1}$ (63.1), maximum number of seeds (1.6), maximum seed weight $(28.38 \mathrm{~g})$ and higher grain yield $(25.13 \mathrm{q})$ recorded at $\mathrm{T}_{9}(\mathrm{NPK}$
@100\%,Zn@100\% 20:40:20Kg NPK+20 $\mathrm{Kg} \mathrm{Zn} \mathrm{ha}{ }^{-1}$ ) and minimum number of pods plant $^{-1}$ (54.6), number of seeds (1.06), seed weight $(24.35 \mathrm{~g})$ and grain yield $(20.25 \mathrm{q})$ recorded at $\mathrm{T}_{1}$ (control). Similar result reported by Rajput (2018) (Fig. 1-3).

Table.1 Treatment combination of chickpea

\begin{tabular}{|c|c|c|}
\hline TREATMENT & TREATMENT COMBINATION & SYMBOL \\
\hline $\mathrm{T}_{1}$ & Control (Absolute control ) & $\mathrm{L}_{1} \mathrm{~F}_{1}$ \\
\hline $\mathrm{T}_{2}$ & @NPK 0\%,@Zn 50\% 10kg Zn ha ${ }^{-1}$ & $\mathrm{~L}_{1} \mathrm{~F}_{2}$ \\
\hline $\mathrm{T}_{3}$ & @NPK 0\%,@Zn 100\% 20 kg Zn ha ${ }^{-1}$ & $\mathrm{~L}_{1} \mathrm{~F}_{3}$ \\
\hline $\mathrm{T}_{4}$ & @NPK 50\%,@Zn 0\% 10:20:10 Kg NPK ha ${ }^{-1}$ & $\mathrm{~L}_{2} \mathrm{~F}_{1}$ \\
\hline $\mathrm{T}_{5}$ & @NPK 50\%,@Zn 50\% 10:20:10 Kg NPK+10Kg Zn ha $^{-1}$ & $\mathrm{~L}_{2} \mathrm{~F}_{2}$ \\
\hline $\mathrm{T}_{6}$ & @NPK 50\%,@Zn 100\% 10:20:10Kg NPK+20Kg Zn ha-1 & $\mathrm{L}_{2} \mathrm{~F}_{3}$ \\
\hline $\mathrm{T}_{7}$ & @NPK 100\%,@Zn 0\% 20:40:20 Kg NPK ha ${ }^{-1}$ & $\mathrm{~L}_{3} \mathrm{~F}_{1}$ \\
\hline $\mathrm{T}_{8}$ & @NPK 100\%,@Zn 50\% 20:40:20Kg NPK+10 Kg Zn ha ${ }^{-1}$ & $\mathrm{~L}_{3} \mathrm{~F}_{2}$ \\
\hline $\mathrm{T}_{9}$ & @NPK 100\%,@Zn 100\% 20:40:20Kg NPK+20 Kg Zn ha ${ }^{-1}$ & $\mathrm{~L}_{3} \mathrm{~F}_{3}$ \\
\hline
\end{tabular}

Table.2 Physical analysis of pre sowing soil sample of chickpea

\begin{tabular}{|c|c|c|}
\hline PARTICULARS & RESULT & \multirow{2}{*}{ METHOD EMPLOYED } \\
\hline Textural class & Sandy loam & \\
\hline Sand (\%) & 68.25 & Bouyoucous hydrometer \\
method(1952)
\end{tabular}

Table.3 Chemical analysis of pre sowing soil sample of chickpea

\begin{tabular}{|c|c|c|}
\hline PARTICULARS & RESULT & METHOD EMPLOYED \\
\hline Soil pH & 7.5 & Glass electrode, pH meter (Jackson 1958) \\
\hline $\mathrm{EC}\left(\mathrm{dSm}^{-1}\right)$ & 0.17 & Digital Conductivity meter (Wilcox 1950) \\
\hline Organic carbon $(\%)$ & 0.65 & $\begin{array}{l}\text { (Walkley and Black’s 1947) } \\
\text { Wet Oxidation Method }\end{array}$ \\
\hline Available nitrogen $\left(\mathrm{kg} \mathrm{ha}^{-1}\right)$ & 285 & (Subbaih and Asija, 1956) Kjeldahl Method \\
\hline $\begin{array}{c}\text { Available phosphorus } \\
\left(\mathrm{kg} \mathrm{ha}^{-1}\right)\end{array}$ & 23.40 & $\begin{array}{c}\text { (Olsen et al. 1954) } \\
\text { Colorimetric method }\end{array}$ \\
\hline Available potassium $\left(\mathrm{kg} \mathrm{ha}^{-1}\right)$ & 118.55 & $\begin{array}{l}\text { (Toth and Prince, 1949) } \\
\text { Flame photometric method }\end{array}$ \\
\hline Available zinc $\left(\mathrm{kg} \mathrm{ha}^{-1}\right)$ & 0.60 & (Shaw and Dean1952) \\
\hline
\end{tabular}


Table.4 Effect of different levels of NPK and Zinc on growth and yield parameters of chickpea

\begin{tabular}{|c|c|c|c|c|c|c|}
\hline Treatment & $\begin{array}{c}\text { Plant } \\
\text { height }(\mathrm{cm})\end{array}$ & $\begin{array}{c}\text { No. of } \\
\text { branches }\end{array}$ & $\begin{array}{c}\text { No. of pods } \\
\text { plant }^{-1}\end{array}$ & $\begin{array}{c}\text { No. of } \\
\text { seeds pod }\end{array}$ & $\begin{array}{c}\text { Seed } \\
\text { weight }(\mathrm{g})\end{array}$ & $\begin{array}{c}\text { Total grain yield } \\
\left(\mathrm{q} \mathrm{ha}^{-1}\right)\end{array}$ \\
\hline $\mathrm{T}_{1}$ & 39.7 & 16.8 & 54.6 & 1.06 & 24.35 & 20.25 \\
\hline $\mathrm{T}_{2}$ & 40.6 & 17.2 & 55.76 & 1.13 & 25.20 & 20.86 \\
\hline $\mathrm{T}_{3}$ & 40.9 & 17.6 & 56.26 & 1.2 & 26.56 & 21.73 \\
\hline $\mathrm{T}_{4}$ & 40.9 & 17.8 & 58.66 & 1.13 & 25.45 & 21.22 \\
\hline $\mathrm{T}_{5}$ & 41.5 & 18.0 & 57.53 & 1.26 & 26.68 & 22.50 \\
\hline $\mathrm{T}_{6}$ & 42.0 & 18.0 & 60.46 & 1.23 & 27.72 & 23.15 \\
\hline $\mathrm{T}_{7}$ & 42.0 & 18.4 & 59.26 & 1.23 & 27.18 & 22.95 \\
\hline $\mathrm{T}_{8}$ & 42.2 & 19.0 & 61.6 & 1.46 & 28.18 & 23.43 \\
\hline $\mathrm{T}_{9}$ & 42.9 & 19.6 & 63.1 & 1.6 & 28.38 & 25.13 \\
\hline F-test & $\mathrm{S}$ & $\mathrm{S}$ & $\mathrm{S}$ & $\mathrm{S}$ & $\mathrm{S}$ & $\mathrm{S}$ \\
\hline S. Em. $( \pm)$ & 0.18 & 0.20 & 0.68 & 0.06 & 0.42 & 0.49 \\
\hline C.D at 5\% & 0.55 & 0.59 & 2.04 & 0.17 & 1.27 & 1.47 \\
\hline
\end{tabular}

Table.5 Effect of NPK and Zinc on physical and chemical properties of soil after harvest of chickpea

\begin{tabular}{|l|c|c|l|l|l|l|l|l|l|l|l|}
\hline Treatment & $\begin{array}{l}\text { Bulk } \\
\text { Density } \\
\left(\mathrm{Mg} \mathrm{m}^{-3}\right)\end{array}$ & $\begin{array}{l}\text { Particle } \\
\text { density } \\
\left(\mathrm{Mg} \mathrm{m}^{-3}\right)\end{array}$ & $\begin{array}{l}\text { Pore } \\
\text { Space } \\
(\%)\end{array}$ & $\begin{array}{l}\text { Solid } \\
\text { Space } \\
(\%)\end{array}$ & $\begin{array}{l}\text { Soil } \\
\mathrm{pH}\end{array}$ & $\begin{array}{l}\mathrm{EC} \\
\left(\mathrm{dSm}^{-1}\right)\end{array}$ & $\begin{array}{l}\text { Organic } \\
\text { Carbon } \\
(\%)\end{array}$ & $\begin{array}{l}\mathrm{N} \\
\left(\mathrm{kg} \mathrm{ha}^{-1}\right)\end{array}$ & $\begin{array}{l}\mathrm{P} \\
\left(\mathrm{kg} \mathrm{ha}^{-1}\right)\end{array}$ & $\begin{array}{l}\mathrm{K} \\
\left(\mathrm{kg} \mathrm{ha}^{-1}\right)\end{array}$ & $\begin{array}{l}\mathrm{Zn} \\
\left(\mathrm{kg} \mathrm{ha}^{-1}\right)\end{array}$ \\
\hline $\mathrm{T}_{1}$ & 1.28 & 2.39 & 46.44 & 53.55 & 7.8 & 0.18 & 0.54 & 281.50 & 26.38 & 145.71 & 0.63 \\
\hline $\mathrm{T}_{2}$ & 1.25 & 2.40 & 47.91 & 52.08 & 7.5 & 0.17 & 0.58 & 285.35 & 26.75 & 149.35 & 0.85 \\
\hline $\mathrm{T}_{3}$ & 1.27 & 2.41 & 47.30 & 52.69 & 7.4 & 0.16 & 0.62 & 287.72 & 26.43 & 156.25 & 0.69 \\
\hline $\mathrm{T}_{4}$ & 1.22 & 2.42 & 49.58 & 50.41 & 7.0 & 0.13 & 0.63 & 291.30 & 27.85 & 173.15 & 0.72 \\
\hline $\mathrm{T}_{5}$ & 1.26 & 2.42 & 47.93 & 52.06 & 7.2 & 0.15 & 0.66 & 292.47 & 27.45 & 178.25 & 0.77 \\
\hline $\mathrm{T}_{6}$ & 1.24 & 2.47 & 49.79 & 50.20 & 7.3 & 0.14 & 0.69 & 294.63 & 28.15 & 176.78 & 0.83 \\
\hline $\mathrm{T}_{7}$ & 1.23 & 2.45 & 49.79 & 50.20 & 7.0 & 0.14 & 0.72 & 298.85 & 28.32 & 203.62 & 0.81 \\
\hline $\mathrm{T}_{8}$ & 1.21 & 2.46 & 50.81 & 49.18 & 7.1 & 0.15 & 0.73 & 304.15 & 28.64 & 209.81 & 0.85 \\
\hline $\mathrm{T}_{9}$ & 1.22 & 2.48 & 50.80 & 49.19 & 7.2 & 0.16 & 0.76 & 306.24 & 28.96 & 210.23 & 0.89 \\
\hline F-test & $\mathrm{NS}$ & $\mathrm{S}$ & $\mathrm{S}$ & $\mathrm{S}$ & $\mathrm{S}$ & $\mathrm{S}$ & $\mathrm{S}$ & $\mathrm{S}$ & $\mathrm{S}$ & $\mathrm{S}$ & $\mathrm{S}$ \\
\hline S. Em. $( \pm)$ & 0.02 & 0.01 & 0.33 & 0.15 & 0.10 & 0.01 & 0.01 & 1.77 & 0.68 & 1.36 & 0.01 \\
\hline C.D at 5\% & 0.07 & 0.04 & 0.99 & 0.45 & 0.31 & 0.02 & 0.04 & 5.31 & 2.02 & 4.08 & 0.03 \\
\hline
\end{tabular}


Fig.1 Effect of NPK and Zinc on availability of nitrogen, phosphorus and potassium in soil after harvest of chickpea

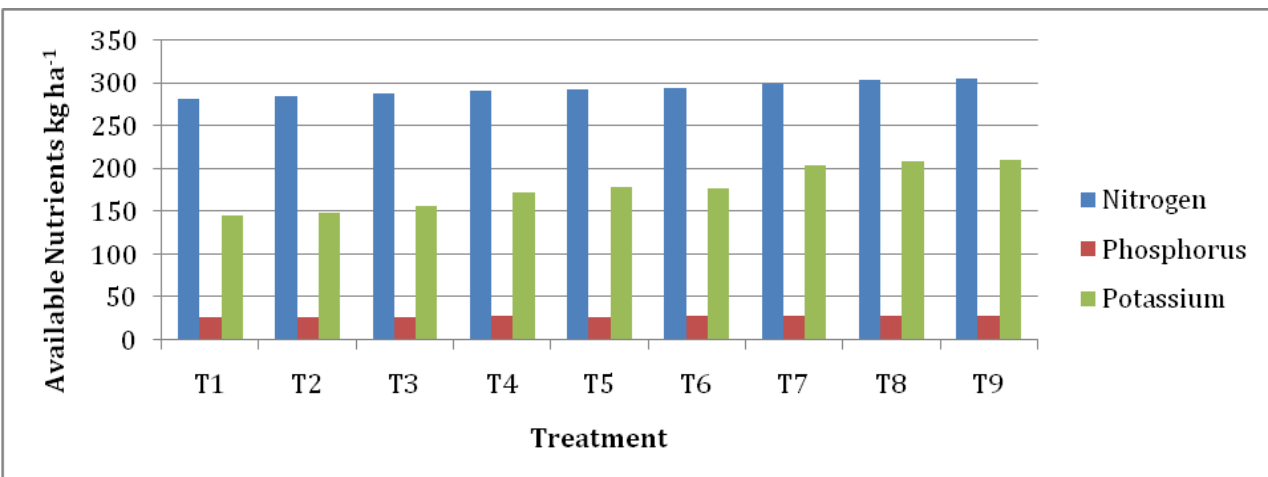

Fig.2 Effect of NPK and Zinc on availability of Zinc on soil after harvest of chickpea

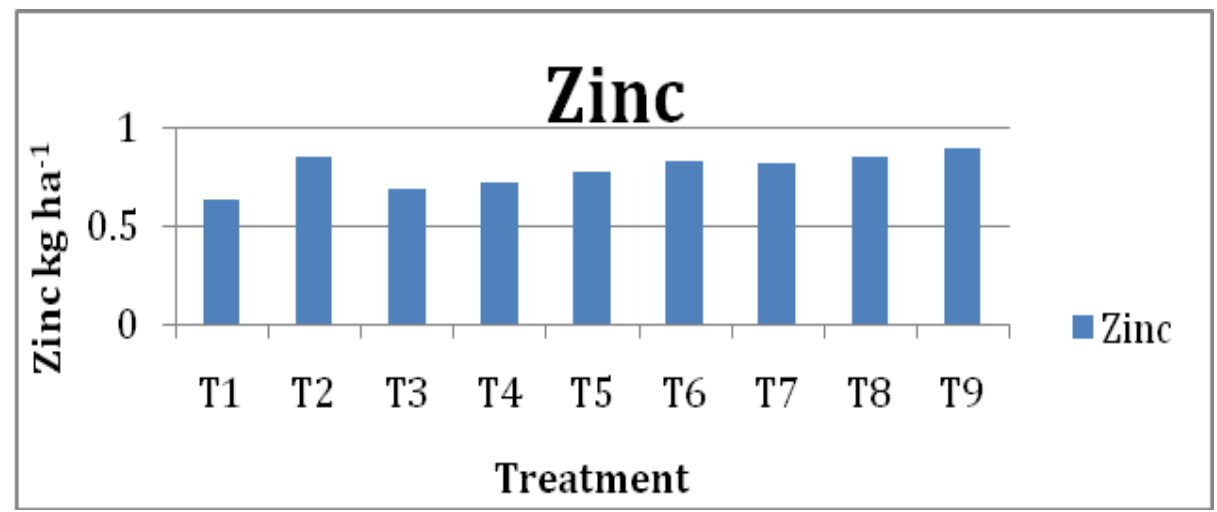

Fig.3 Effect of NPK and Zinc on Soil pH, electrical conductivity and organic carbon of soil after harvest of chickpea

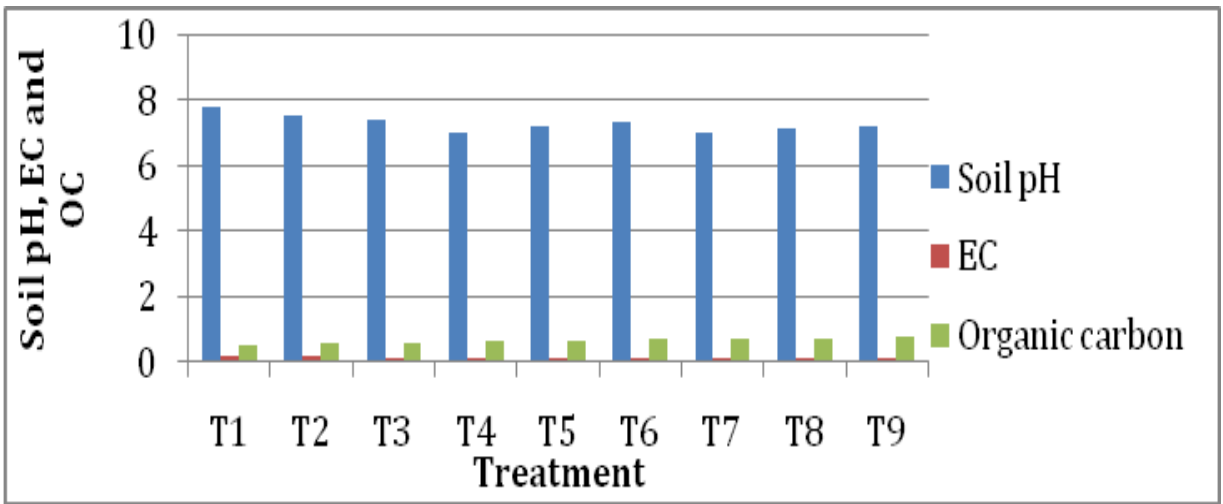

Physical and Chemical Properties of soil

There is non significant effect of treatment combination on bulk density. The maximum bulk density (1.28) was recorded at $T_{1}$
(Control) and minimum value (1.21) recorded at $\mathrm{T}_{8}$ (NPK $100 \%, \mathrm{Zn} \quad 50 \% \quad 20: 40: 20 \mathrm{Kg}$ $\left.\mathrm{NPK}+10 \mathrm{Kg} \mathrm{Zn} \mathrm{ha}{ }^{-1}\right)$. Treatments shows the significant effect on particle density, the maximum value of particle density (2.48) 
recorded at $\mathrm{T}_{9}$ (NPK 100\%, $\mathrm{Zn} \quad 100 \%$ 20:40:20Kg NPK+20 Kg Zn ha $^{-1}$ ) and minimum value (2.39) recorded at $\mathrm{T}_{1}$ (Control).Treatments show the significant effect on pore space. The value of pore space was maximum $(50.81 \%)$ at $\mathrm{T}_{8}$ (NPK @ $100 \%$, Zn@ 50\% 20:40:20Kg NPK+10Kg Zn ha ${ }^{-1}$ ) and minimum pore space $(46.44 \%)$ at $\mathrm{T}_{1}$ (Control).The higher value of $\mathrm{pH}$ (7.8) recorded at $\mathrm{T}_{1}$ (Control) followed by 7.5 at $\mathrm{T}_{2}$ (NPK 0\%, Zn 50\% 10kg Zn ha ${ }^{-1}$ ). The lower $\mathrm{pH}$ (7) at $\mathrm{T}_{7}$ (NPK 100\%, Zn 0\% 20:40:20 Kg NPK ha ${ }^{-1}$ ) Similar result reported by Zhong et al., (2014). The maximum value of electrical conductivity (0.18) of the soil was recorded at $\mathrm{T}_{1}$ (Control) and minimum value (0.13) recorded at $\mathrm{T}_{4}$ (NPK 50\%, Zn 0\% 10:20:10 $\mathrm{Kg}$ NPK $\mathrm{ha}^{-1}$ ). Treatments show the significant effect. The maximum value of organic carbon (0.76) was recorded at $\mathrm{T}_{9}$ (NPK 100\%, Zn 100\% 20:40:20Kg NPK+20 $\mathrm{Kg} \mathrm{Zn} \mathrm{ha}{ }^{-1}$ ) and minimum value of organic carbon (0.54) was recorded at $\mathrm{T}_{1}$ (Control). There is significant effect of treatments on availability of nitrogen. The maximum amount of nitrogen $\left(306.24 \mathrm{~kg} \mathrm{ha}^{-1}\right)$ recorded at $\mathrm{T}_{9}$ (NPK 100\%, Zn 100\% 20:40:20Kg $\mathrm{NPK}+20 \mathrm{Kg} \mathrm{Zn} \mathrm{ha}{ }^{-1}$ ) and minimum nitrogen $\left(281.5 \mathrm{~kg} \mathrm{ha}^{-1}\right.$ ) recorded at $\mathrm{T}_{1}$ (control). There is significant effect of treatments on availability of phosphorus. The higher amount of phosphorus $\left(28.96 \mathrm{~kg} \mathrm{ha}^{-1}\right)$ recorded at $\mathrm{T}_{9}$ (NPK 100\%, Zn 100\% 20:40:20Kg NPK+20 $\left.\mathrm{Kg} \mathrm{Zn} \mathrm{ha}{ }^{-1}\right)$ and minimum (26.38 $\left.\mathrm{kg} \mathrm{ha}^{-1}\right)$ recorded at $\mathrm{T}_{1}$ (control). Similar result obtained by Kuldeep et al., (2016). The amount of potassium was maximum (210.23 $\mathrm{kg} \mathrm{ha}{ }^{-1}$ ) at $\mathrm{T}_{9}$ (NPK 100\%, Zn $100 \%$ 20:40:20Kg NPK+20 Kg Zn ha $^{-1}$ ) and minimum (145.71 $\mathrm{kg} \mathrm{ha}^{-1}$ ) recorded at $\mathrm{T}_{1}$ (Control). It shows significant effect of treatment combination. The maximum amount of Zinc $\left(0.89 \mathrm{~kg} \mathrm{ha}^{-1}\right)$ recorded at $\mathrm{T}_{9}$ (NPK 100\%, Zn 100\% 20:40:20Kg NPK+20 $\mathrm{Kg} \mathrm{Zn} \mathrm{ha}{ }^{-1}$ which shows the significant effect of treatment combination
It was concluded that the post harvest soil properties such as $\mathrm{EC}\left(\mathrm{dSm}^{-1}\right)$, available Nitrogen, Phosphorus, Potassium and Zinc were found to be significant with increasing level of NPK and zinc. The treatment combination $\mathrm{T}_{9}$ (NPK@100\%, Zn@100\% 20:40:20 Kg NPK+20 Kg Zn ha ${ }^{-1}$ ) was found to best in term of particle density, pore space $(\%)$, organic carbon(\%), available nitrogen, phosphorus, potassium and zinc as $2.48,50.80,0.76,306.24,28.96,210.23$ and 0.89 respectively. Its found to be the best treatment for maximum growth and yield parameter and gave highest net profit of (Rs.124849) ha $^{-1}$ and recorded highest Benefit Cost ratio (1:4.24). It could be recommended for profitable cultivation of chick pea and maintain the soil health.

\section{Acknowledgement}

I am grateful for constant inspiration and encouragement, valuable help and advice throughout the study period and investigation from the head of the department and staff, Department of Soil Science and Agricultural Chemistry, SHUATS Prayagraj, Uttar Pradesh.

\section{References}

Devi, P., S. Darvhankar, A. Prakash and Diptanu Banik,(2019) Effect of different doses of nitrogen on growth and yield of chickpea (cicer arietinum L.), Plant Archives Vol. 19, Supplement 1, pp. 458460.

Dotaniya ML, Datta SC, Biswas DR, Kumar K. (2014), Effect of organic sources on $\mathrm{P}_{2} \mathrm{O}_{5}$ fraction and available $\mathrm{P}_{2} \mathrm{O}_{5}$ in typical Haplustept J. Indian Soc. Soil Sci. 62(1):80-83.

El Habbasha, S.F., Magda H. Mohamed, 11 E.M. Abd El-Lateef, B.B. Mekki and M.E. Ibrahim, (2016) Effect of Combined Zinc and Nitrogen on Yield, 
Chemical Constituents and Nitrogen Use Efficiency of Some Chickpea Cultivars under Sandy Soil Conditions, World Journal of Agricultural Sciences 9 (4): 354-360.

Kuldeep Balai, M Jajoria, $\mathrm{R}$ Verma, $\mathrm{P}$ Deewan and SK Bairwa,(2017) Nutrient content, uptake, quality of chickpea and fertility status of soil as influenced by fertilization of Phosphorus and Zinc, Journal of Pharmacognosy and Phytochemistry, 6(1): 392-398.

Kumar, D., Arvadiya LK, Kumawat AK, Desai, Patel TU(2014), Yield, Protein Content, Nutrient Content and their Uptake in Chickpea (Cicer arietinum L.) as Influenced by Graded Levels of Fertilizers and Bio Fertilizers. Trends in Biosciences. 7(24):42294233.

Pingoliya, K.K., A.K. Mathure, M.L. Dotaniya, D.K. Jajoria and G.P. Narolia (2013) Effect of phosphorus and iron level on growth and yield attributes of chickpea (Cicer arietinum L.), Legume
Res.,37 (5): 537-541.

Rajput, A. (2018) Potassium Application on Chickpea Crop under Irrigated Area. Sarhad Journal of Agriculture, 34(4): 941-947

Shukla, A.K., et al., (2019) "Yield gap analysis in kabuli chickpea through front line demonstration." International journal of Agriculture Sciences 11, (2), 7770-7772.

Sudhanshu Verma, A. Singh, Swati S. Pradhan, JP Singh and SK Verma (2018), effects of organic formulations and synthetic fertilizer on the performance of pigeonpea in eastern region of Uttar Pradesh, Bangladesh J. Bot. 47(3): 467-471.

Zhong, H., et al., (2014). Effect of different nitrogen application on soil physical, chemical properties and yield in maize (Zea mays L.), Agricultural Sciences, 5, 1440-1447.

\section{How to cite this article:}

Ankur Sahu, Narendra Swaroop, Arun Alfred David and Tarence Thomas. 2020. Effect of Different Levels of NPK and Zinc on Soil Health Growth and Yield of Chickpea (Cicer arietinum L.) var. PUSA 362. Int.J.Curr.Microbiol.App.Sci. 9(10): 591-597. doi: https://doi.org/10.20546/ijcmas.2020.910.070 